\title{
仮想環境を用いた筋電義手訓練システムにおけるタスク難易度調整の効果 Effect of Task Difficulty Adjustment in Operation Training of
Myoelectric Prosthetic Hand using Virtual Environment
}

竹内豊計*,**(正会員)，和田隆広*(正会員)，向原真斗*(非会員），土居俊一*(非会員）， Toyokazu Takeuchi*** Takahiro Wada* , Masato Mukoubaru*, and Shun'ichi Doi *

\begin{abstract}
Myoelectric prosthetic hands improve ADL largely because the hand uses EMG signal induced by voluntary contraction of residual muscles of amputees for opening and closing the hand and the amputees can control its motion intuitively. On the other hand, it is difficult for the amputees to gain skills to use the prosthesis including precise EMG control ability required to control the prosthesis. In this paper, a new training system of Myoelectric prosthetic hand for upper limb amputees is developed using virtual reality technology in which amputee can train in the virtual environment. We hypothesize that efficacy of training depends on difficulty of given task. Thus, we propose a new training method that controls the success rate of given tasks by changing difficulty of the task in the virtual environment based on the trainee's skill level. The experimental results will show that the proposed method can control success rate of the given task by changing task difficulty according to the user's skill level. Further, it is shown that the success rate of the given task increases when the task difficulty is adjusted by the proposed training method.
\end{abstract}

\section{Key Words}

EMG Prosthetic Hand, Task Difficulty Adjustment, Virtual Environment, Training System

\section{1. はじめに}

筋電義手は, 切断肢の残された筋肉を随意的に収縮させ 筋電位を取り出し, モーターでハンドの開閉動作を行う義手 である. 他の能動義手より把持力は強力であり, ハンド開閉の ためのハーネス等の必要もなくなる. そのため切断者の日常 生活動作向上及び生活の質 (QOL) の向上に有用である. [1]. その一方で, 利用者が筋電義手をコントロールするため

\section{0 年 5 月 6 日受理}

\section{1 年 6 月 16 日最終原稿受理}

* 香川大学工学部. 香川県高松市林町 2217-20

*** 株式会社オルトリハ・システム. 香川県木田郡三木町池戸 1551-6

* Faculty of Engineering, Kagawa University , 2217-20 Hayashi-cho,TakamatsuKagawa JAPAN

** Orthoreha System Co.,ltd., 1551-6 Ikenobe Miki-cho Kita-gun Kagawa JAPAN
には, 実行するタスクに応じて筋電位を正確に出力するとい った，筋電位制御能力の獲得訓練が必要である。また切 断者は実際に筋電義手を製作し, 訓練後でないと筋電義手 の有用性を理解しにくいという問題もある.

現在, 臨床現場においては, 以下のような方法で筋電義 手の処方と訓練が行われている[2].まずオリエンテーションと 断端等の評価を行った後に, 実際に筋電義手のハンドの貸 出を行い, 仮筋電義手を製作寸る. 施設内において義手操 作訓練を行った後に自宅での使用を試みる.この方法は筋 電義手に精通した医師, セラピス卜, 義肢装具士のチームア プローチによってなされている. また訓練結果の評価はセラピ ストの経験によるところが大きい. そのため, 筋電義手の普及 にはより簡便に, 客観的に訓練, 評価ができる手法が望まれ ている.

このような背景から，近年仮想環境を利用した筋電義手 訓練が多く研究されている. 仮想筋電義手訓練システムでは, 実際の義手を用いることなくコンピュータ上で利用可能なこと 
から簡便に訓練ができ, 客観的かつ多様な評価ができると期 待される.たとえば MyoBoy ${ }^{\circledR}$ は商品化された筋電義手訓練 システムである[3]. 筋電義手製作の際に筋電位の導出が可 能か否かの判定に用いたり, その後の筋電義手操作訓練に 使用でき，モニター上で小児の使用を考慮しゲームのような 機能を持たせたり, ハンドを描写し開閉および回内外を視覚 的に確認できるようになっている.ただし, Otto Bock 社製の 筋電義手システムの訓練専用である. Lovely et al.[4]は, ビ デオゲームの要素を取り入れてモチベーションを維持する訓 練手法システムを同様に提案している. またこのような訓練シ ステムにおいて, 利用者の制御能力を指標化する研究も行 われている. 例えば Dupont et al.[5]は, コンピュータグラフ イクスで描画された画面上の義手を用いて行う訓練システム を提案し, 画面内の義手ハンドの開度の制御性能や時間応 答などから制御能力の指標化に取り組んでいる. 最近では大 里[6]らは仮想環境を用いた訓練装置における視覚呈示の 影響を詳細に調査すると共に, 訓練効果の指標化を試みて いる. また, より複雑な筋電位制御能力の訓練を目的とし, 辻 ら[7]は多チャンネルの筋電位による筋電操作トレーニングシ ステムを提案している. なお多様な個人毎のスキルの差異を どのように訓練に反映するかを検討した研究は見当たらな い.

本研究では, 筋電位の導出訓練及び分離訓練を終了した ものを対象とする. このような対象者においては個々人の能 力に対応した難易度の訓練タスクを課すことにより, 訓練効 果が向上すると考える. そこで個々人の筋電位制御能力を把 握し, タスク難易度を調整する訓練手法を提案する. タスクの 難易度がスキル上昇に応じて変化するため, 継続利用の効 果も期待できる. 本論文ではまず, 基本的な筋電位出力の能 力を有した切断者を対象とし, 日常生活によく見られる物体 のピックアンドプレースタスクを行う仮想筋電義手訓練システ ムを開発する. また, 利用者の筋電位制御能力に応じて最大 許容力を変化させることによってタスク難易度を調整する訓 練手法を導入し, 実験により訓練効果に及ぼす影響を調査 する.

\section{2. 仮想筋電義手システム}

\section{1.システム構成}

本研究では Fig. 1, 2 に示すような仮想筋電義手システム を開発した. 本システムは切断者の筋電位信号と上肢の姿 勢を入力として仮想空間内の義手の開閉速度／把持力と上 肢の姿勢を制御し, 仮想空間内で把持動作訓練が可能なシ ステムである。

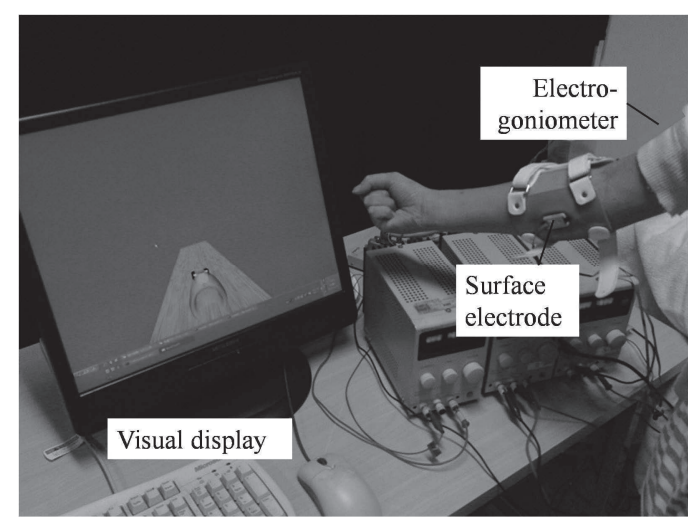

Fig.1. 仮想筋電義手訓練システム

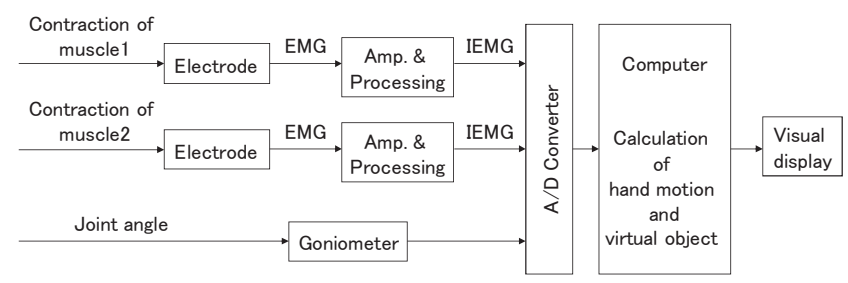

Fig.2. システム構成図

表面筋電位信号は, 生体アンプ (Otto Bock 社製 MYOBOCK ${ }^{\circledR}$ Electrode,linear 13E200=60)を用いて取得 する. 取得した筋電位 $(\mathrm{EMG})$ を $\mathrm{A} / \mathrm{D}$ 変換しサンプリング周 波数 $60 \mathrm{~Hz}$ にて計算機に取り込む. 上肢の姿勢はゴニオメー タ (Penny\&Giles 社製)で計測し, A/D 変換を行い計算機に 取り込む. なおゴニオメータで計測した肘姿勢に比例して, 仮 想空間内のハンドが上下する.これらの入力信号に基づき, 仮想空間内において義手で対象物を把持し, 上下移動する ことが可能である. 表面筋電位信号は前腕の背屈筋群と掌 屈筋群の 2 箇所で計測している. 各々の筋電位にハンドの開, 閉の動作が割り当てられている.

視覚ディスプレイ中には, 机と正方形の対象物および, 2 本 の指に簡略化されたバーチャルハンドが表示されている. 筋 電位入力により, バーチャルハンドが開閉される. また, 適切 な把持力の状態において, 肘に取り付けられたゴニオメータ が肘屈曲を検出すると対象物を把持した状態で持ち上げら れる. なお対象物は, 最大許容力を超えた握力が加わると赤 色へ変わり，破壊されたことを示す．

本システムでは筋電位の大きさによって連続的に開閉速 度や把持力を制御できるいわゆる比例制御式義手を想定す る.ここでは簡便なモデルを利用することを考え, 例として MYOBOCK ハンドの静特性を予備実験にて解析した. その 結果に基づいて, 筋電位入力に対するハンド開閉速度およ び把持力応答を以下のようにモデル化した. まず, 筋電位入 力に対するハンド開閉速度 $\dot{\theta}(t)((\dot{\theta}(t)>0)$ は開方向 $)$ は式 (1)によってモデル化される. 


$$
\dot{\theta}(t)=\left\{\begin{array}{cl}
a x_{1}^{2} & \left(x_{1}-x_{2} \leq \varepsilon\right) \\
-a x_{2}^{2} & \left(x_{1}-x_{2} \geq \varepsilon\right) \\
0 & (\text { else })
\end{array}\right.
$$

ここに $x_{1}, x_{2}$ はそれぞれ, 生体アンプから得られる平滑化され た掌屈筋群, 背屈筋群の表面筋電信号を表している. また $a$ は正定数, $\mathcal{E}$ は不感帯を設けるための微小值である.

またハンドと物体が接触している場合における, ハンドの把 持力 $F(t)$ は以下の式(2)によってモデル化する. なお本論 文では, 把持力を強める方向を主として扱うため把持力を弱 めるといったハンドの動作はモデルに含まれない.

$$
F(t)= \begin{cases}b\left(\max \left\{x_{1}(\tau)\right\}\right)^{2}, & \tau \in\left[t_{c}, t\right] \\ 0 & \left(x_{1}(t) \geq x_{2}(t)\right) \\ & \left(x_{1}(t)<x_{2}(t)\right)\end{cases}
$$

ここに $b$ は正定数, $t_{\mathrm{c}}$, はハンドと対象物が触れ始めた時刻を 表わしている.

Fig.3 は筋電位と算出された把持力の例である. 対象物に 触れているのは約 2 秒から筋肉 2 が収縮する 12 秒までの間で ある. 式(2)の把持力の定義から, 把持力は筋電位の最大值 で保持される.
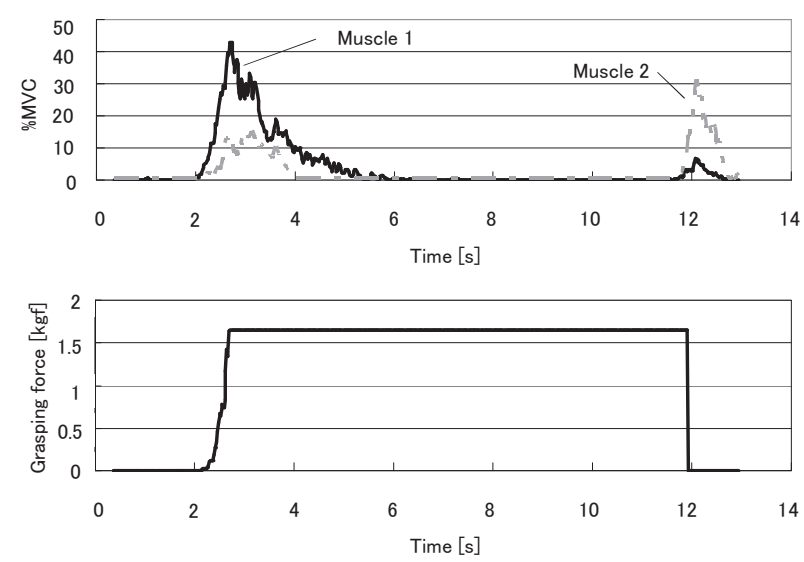

Fig.3. 筋電位と把持力の関係

Fig.4に本システムにおけるピックアンドプレースタスクのフ ローチャートを示す. なお把持力制御がタスクの成否を決定 しているため, この図では把持力判定部に対して詳述してい る. 訓練開始時, 対象物は机面上に置かれている. また, 八 ンドは対象物と同じ高さにあり, ハンドの間に配置された状態 から訓練がスタート寸る.この状態において掌屈筋群の EMG が入力されることによって仮想環境内のハンドが閉じられ物 体と接触する. その後, 把持力の判定を行い, 把持力が $F \in\left[F_{\min }, F_{\max }\right]$ の範囲に収まっている場合には持ち上げ可 能状態となる. 不等式 $F<F_{\min }$ が成立する場合にゴニオメー タからの訓練者の持ち上げ意図を検出すると対象物はハンド から滑り落ちる. また $F>F_{\max }$ の場合には対象物は破壊され
る.この対象物の持ち上げ状態においても把持力判定を行 い, 物体の落下および破壊の可能性がある. 再び訓練者の 操作によって対象物が机上に戻された後, 背屈筋群の EMG が入力されるとハンドが対象物から離れる.

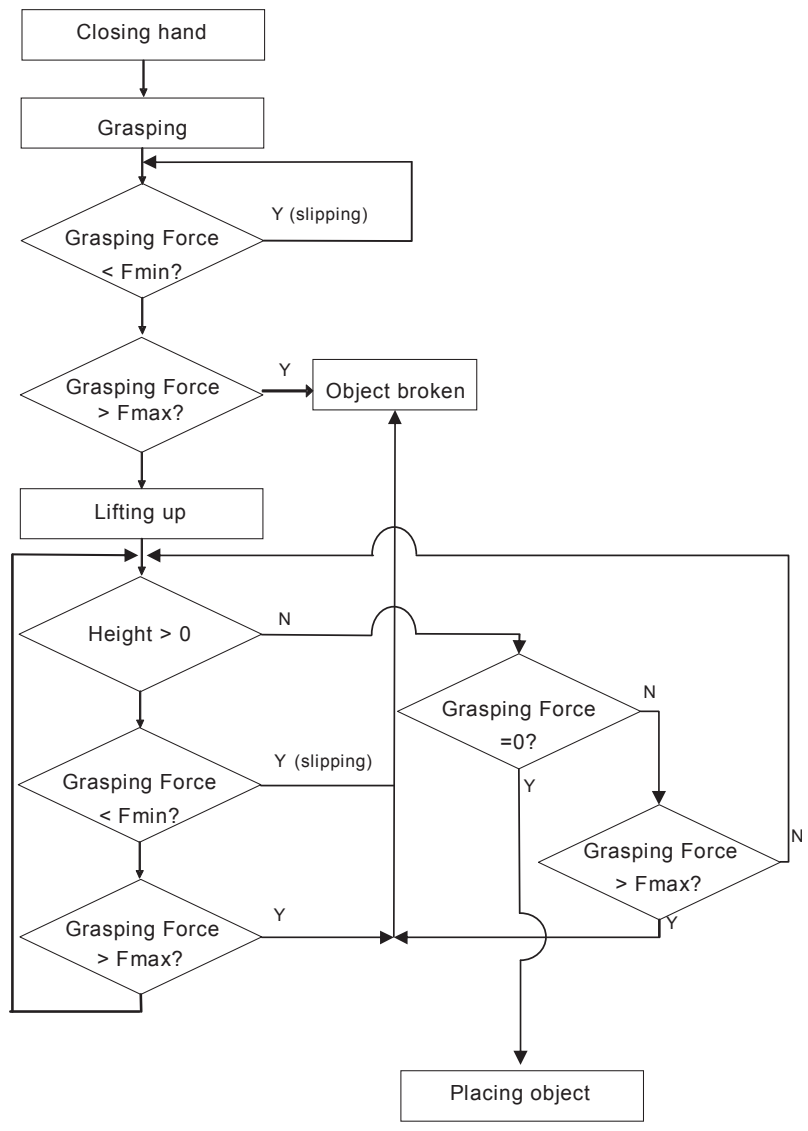

Fig.4 ピックアンドプレースタスクの手順

\section{2.タスク難易度調整による訓練手法}

仮想環境内の対象物として脆い物を想定する. 訓練者は, ピックアンドプレースタスクにおいて, 把持力をある特定の範 囲内 $F \in\left[F_{\min }, F_{\max }\right]$ にコントロールする必要がある. そのため, 筋電位をある範囲内にコントロールする必要がある.

ここで, 筋電義手における筋電位制御能力向上について 考える. 義手には通常, 握力や触覚のフィードバックは無い ため, 使用者は物体を落としたり, 壊したりといった失敗と, 成 功の結果を見て, はじめて筋電位出力指令が変更される. そ のため, 訓練においてもタスクの成功率が訓練効果に大きな 影響を及ぼすと考えられる。

そこで本研究では, 訓練者の筋電位制御能力を評価し, 能 力に応じたタスク難易度を設定する訓練手法を提案する. 例 えば, 訓練者の握力を $F \in\left[F_{\min }, F_{\text {max }}\right]$ の範囲で維持すること が難しく, 把持力が $F_{\max }$ より大きい場合, 最大許容力を, 式 (3)のように仮想環境内でより高く設定することとする. 


$$
F_{\text {max }}^{a d}=F_{\max }+\Delta
$$

ここで $F_{\max }^{\mathrm{ad}}$ は変更後の物体の最大許容力であり, $\Delta$ は対象物

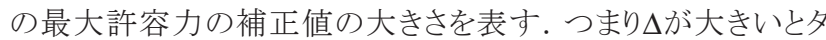
スク難易度は下がる. $\Delta$ は訓練者の現段階のスキルに基づい

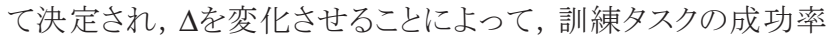
を適切に変化させることができると期待される。

\section{3. 訓練手法の検証実験}

\section{1. 実験タスク}

実験参加者は立位において, 仮想環境内にある机上の対 象物を把持し, 时の屈曲の最大角度まで持ち上げ, 約 3 秒 間この姿勢を維持し机上に戻すタスクを課された。本実験で は, 対象物を落下させたり, 破壊させると失敗とした。対象物 に設定した最大許容力以上の把持力を出力すると対象物が 赤色に変化し対象物が破壊されたことを視覚的に表示する.

\section{2. 実験条件}

Table.1 に示されるように, タスク難易度調節条件 (以下, TDA 条件) とタスクの難易度を変更しない条件 (以下, control 条件)の 2 つの実験条件を設定した. 訓練は以下の I 期からIII期の 3 フェーズに分けて実施した. なお夕スク難 易度には $F_{\max }, F_{\min }$ の両方が関連すると考えられるが，予備 実験の結果 $F_{\max }$ を越えることによる失敗が多かったため,こ こでは $F_{\max }$ のみを変更することとした。

Table.1. 訓練フェーズ

\begin{tabular}{|c|c|c|c|c|}
\hline & & $\begin{array}{c}\text { Term I } \\
\text { (Trial 1-7) }\end{array}$ & $\begin{array}{c}\text { Term II } \\
(8-17)\end{array}$ & $\begin{array}{c}\text { Term III } \\
(18-27)\end{array}$ \\
\hline \multirow{2}{*}{$\begin{array}{c}\text { TDA } \\
\text { condition }\end{array}$} & $F_{\max }^{\mathrm{ad}}[\mathrm{kgf}]$ & 0.8 & $F_{\text {med }}$ & 0.8 \\
\cline { 2 - 5 } & $F_{\min }[\mathrm{kgf}]$ & & 0.5 \\
\hline \multirow{2}{*}{$\begin{array}{c}\text { Control } \\
\text { condition }\end{array}$} & $F_{\max }[\mathrm{kgf}]$ & & 0.8 \\
\cline { 2 - 5 } & $F_{\min }[\mathrm{kgf}]$ & & 0.5 \\
\hline
\end{tabular}

I 期： 7 試行あり, 被験者のスキルを調査する. 個人スキル を表す指標として，ここでは各試行における最大把持力の， 全試行における中央值 $F_{\text {med }}$ を導入する.つまり,この $F_{\text {med }}$ が小さいほど筫電位制御能力が高く微妙な操作ができると考 えた.

II 期：TDA 条件では，I 期で調査した個人スキルに基づい てタスクの難易度を変化させる. I 期で求めた $F_{\mathrm{med}}$ を, 把持 する物体の最大許容力に設定し, 訓練を行った。つまり, 式 (4)の補正值 $\Delta$, 以下のように決定した.

$$
\Delta=F_{\text {med }}-F_{\max }
$$

この条件で 10 試行の訓練を行う. なお, control 条件では II 期であっても $\Delta=0$ とした.

III期：10 試行あり, 訓練の効果を検証する.
I 期，III 期では個人スキルを評価するために下限 $F_{\min }=0.5 \mathrm{kgf}$, 上限 $F_{\max }=0.8 \mathrm{kgf}$ (control 条件と同条件)で タスクを実行した。

実験参加者は, 本研究に関与しない大学生, 大学院生か ら募った $20 \sim 23$ 歳の健常男性であり, TDA 条件 7 名 (被験 者 $\mathrm{A} \sim \mathrm{G}$ ), control 条件 3 名（被験者 $\mathrm{H} \sim \mathrm{J}$ )であった. なお 被験者には実験内容を十分説明し，同意を得たうえで実施 した.

\section{3. 実験結果}

実験においての傾向を以下に示す. TDA 条件では, 第 I 期では筋電位の出しすぎによる対象物の破損の傾向が多く 見られた。第 II 期では，対象物持ち上げ状態の間に対象物 が落下するケースが散見された. 第III期においては, 対象物 を把持できない状態で義手を挙上しようとする場面がみられ た. 一方 control 軍においては, 全期において対象物の破壊 が多かった。

Fig.5 分布を示す. 訓練前の I 期は広範囲に分布しているのに対 して, 訓練後のIII期では分布が比較的狭くなり，0.8kgf の 周辺への分布が増加し, 把持力が大きな領域における頻度 が低くなった.これより, 訓練の効果により, 許容把持力周辺 に把持力の分布が移行したことがうかがえる.

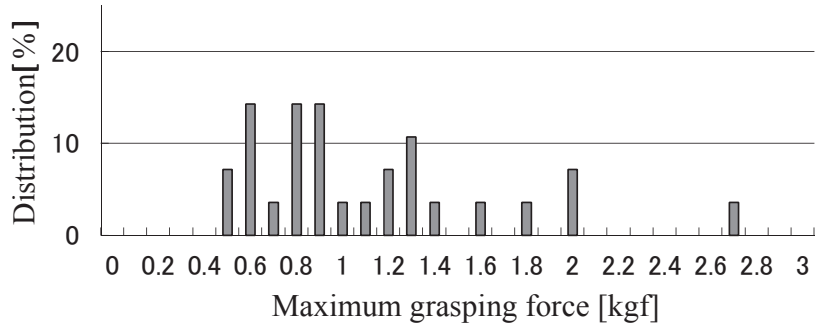

(a) Term I

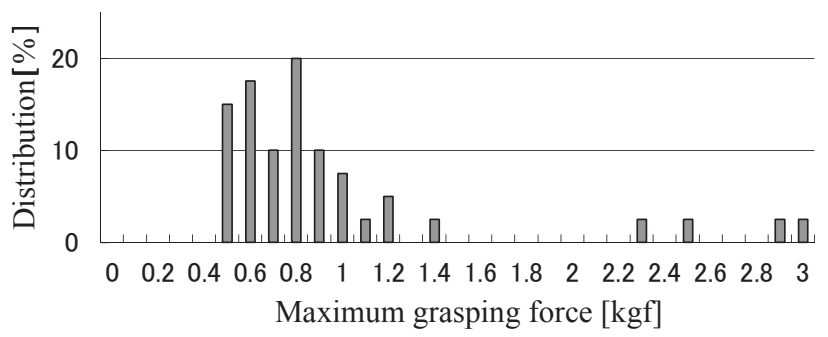

(b) Term III

Fig.5 TDA 条件での最大把持力の分布

Fig.6 に, TDA 条件と control 条件の I 期からIII 期まで のタスク成功率を示す. 被験者が I 期での成功率が低く, 被 験者に十分なスキルが無いことを示している．II期では， control 条件の被験者に比べて, TDA 条件の被験者の成功 率が高くなっており, 仮想空間内の対象物の最大許容力が 増加することによってタスク難易度が下がった効果である. ま 
たIII期では TDA 条件での成功率が control 条件よりも高く なっている. なお実験参加者 $\mathrm{A}$ など I 期の成功率が低い参 加者ではIII期での成功率も大きくならなかった.これは第 I 期， III 期と，第 II 期の難易度が大幅に異なるため，II 期での 訓練効果が十分にIIII期に現れない可能性を示唆寸るもので ある.この点はスキル調查手法などに関わる重要な問題であ り, 今後の課題である. なお control 群の実験参加者 $\mathrm{H}, \mathrm{I}$ において II 期の成功率が上昇したが，期に低下した。この 明確な理由は特定できないが, 高難易度タスク実行による疲 労の影響も一因と推察される.つまり, タスク難易度設定を行 わない条件で, 難易度が非常に高い筋電位出力制御を継続 的に実施し, 参加者は負担を強いられていたと仮定する.こ れにより III 期では疲労によってタスク成功率が低下した可能 性がある.ただし本論文ではタスク難易度と負担や疲労の関 係については対象としないこととする.

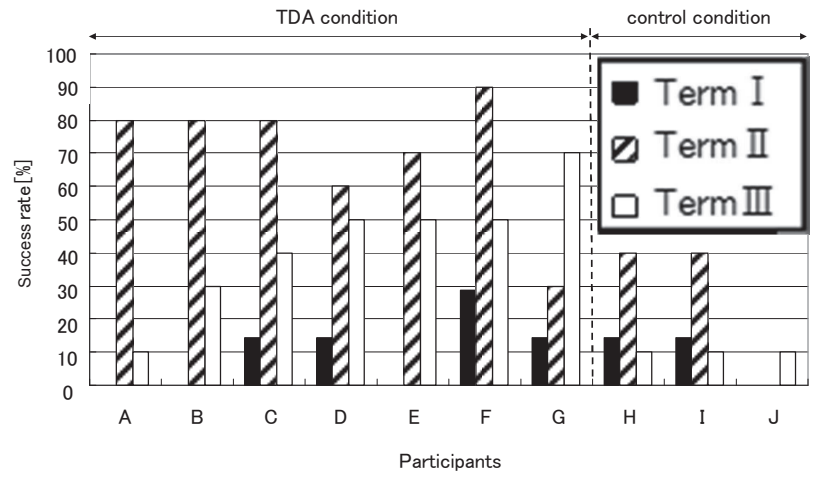

Fig.6. 参加者毎の成功率の変化 (TDA vs Control)

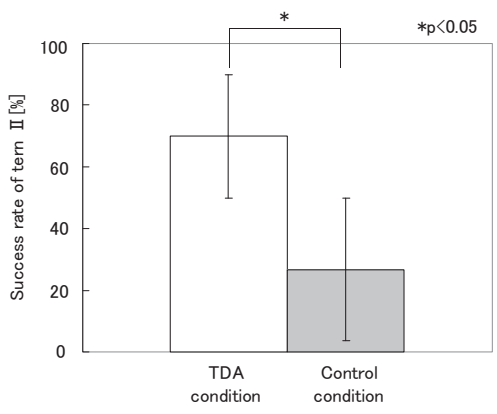

Fig.7. II 期の成功率 (TDA vs Control)

Fig.7 に II 期の成功率の全実験参加者の平均値を示寸. TDA 条件の成功率が control 条件よりも有意に高い (Mann-Whitney U 検定, $\mathrm{p}<0.05$ ).つまり, 提案する夕スク 難易度調整手法により, 訓練中のタスク成功率が有意に変 化できることが示されている. なお, 第 3 期と第 1 期の成功率 の差が訓練による筇電位制御の能力の向上を表すと考える. そこで式(5)によって定義される成功率増加量を訓練条件毎 に比較した結果を Fig8 に示す.

$($ 成功率増加量 $)=($ III 期成功率 $)-(\mathrm{I}$ 期成功率 $)$
TDA 条件で有意に成功率増加量が大きくなった (Mann-Whitney U 検定, $\mathrm{p}<0.05)$. つまり提案する夕スク難 易度調整に基づく訓練手法により, 筋電位制御能力の訓練 効果が高まった。

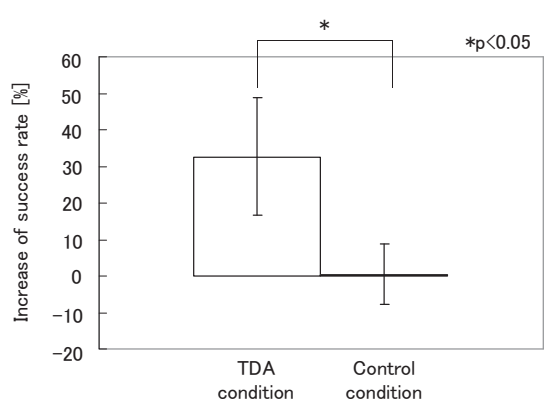

Fig.8. 成功率増加量 (TDA vs Control)

\section{4. タスク難易度の訓練効果への影響}

\section{1.実験条件}

実験条件は第3節と同様である. ただしタスク難易度が訓練 効果に及ぼす影響を調査するため, II 期における補正值 $\Delta$ に ついて, 以下の 4 条件設けた。

1) base 条件: 補正値 $\Delta$ 第 3 節の実験の TDA 条件と同じで あり，I 期の最大把持力の中央值で決定される(式(4)).

2) $1 / 2$ 条件: 補正值 $\Delta$ は base 条件の半分である.つまり, $\Delta=\left(F_{\operatorname{med}} \cdot F_{\max }\right) / 2$ である.

3) 2 倍条件: 補正值 $\Delta$ は base 条件の 2 倍である.つまり, $\Delta=2\left(F_{\text {med }} \cdot F_{\text {max }}\right)$ である.

4) control 条件: 補正值 $\Delta=0$ である.

実験参加者は本研究に関与しない大学生, 大学院生から 募った 20〜23 歳の健常男性であり, base 条件 10 人, 1/2条 件 3 人, 2 倍条件 3 人, control 条件 3 人であった. なお実験 参加者には実験内容を十分説明し, 同意を得たうえで実施 した.

\section{2. 実験結果}

Fig.9 に II 期におけるタスク成功率を示す。 Mann-Whitney の U 検定の結果, base 条件と 2 倍条件の 成功率は $1 / 2$ 条件と control 条件の成功率よりも有意に高か った $(\mathrm{p}<0.05)$.これらの結果から，II 期の成功率は夕スクの難 易度,つまり, 補正量を変化させることによってコントロールす ることが可能であると考えられる。

Fig.10に I 期に対するIIII期の成功率の増加量を示す. 成 功率はbase 条件で最も増加している. 一方, $1 / 2$ 条件では成 功率の増加は見られない. Mann-Whitney の U 検定の結 果, base 条件が他の $1 / 2$ 条件, 2 倍条件, control 条件より も有意に $(\mathrm{p}<0.05)$ 成功率が増加した. 


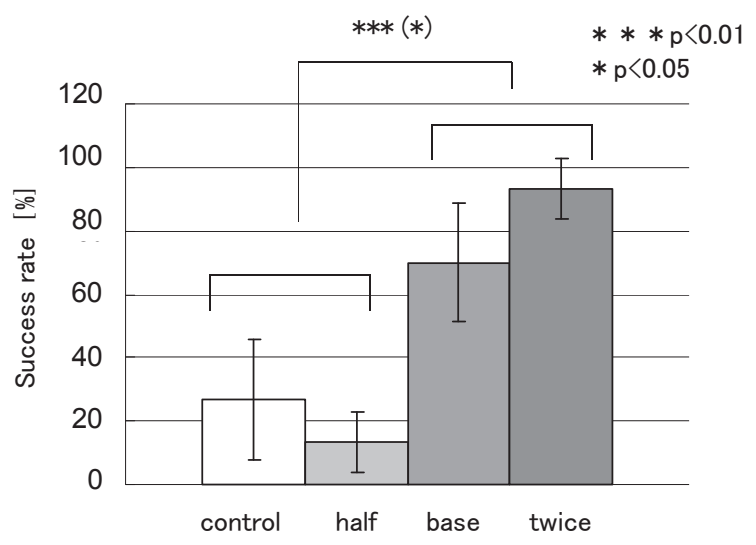

Fig.9. タスク難易度毎の II 期の成功率

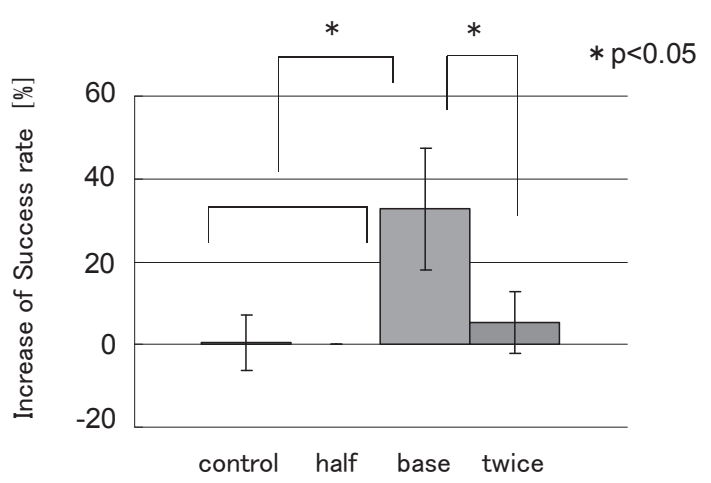

Fig.10. タスク難易度毎の成功率増加量

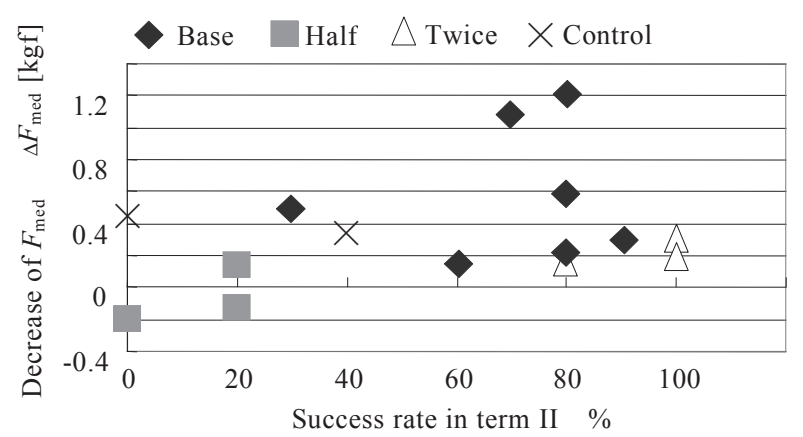

Fig.11. II 期の成功率と $\Delta F_{\text {med }}$ の減少量

Fig.11 は II 期の成功率と, I 期と III 期における $F_{\text {med }}$ の差

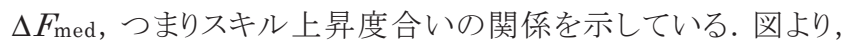
特に II 期の成功率が 60 ～80\%あたりで, $\Delta F_{\text {med }}$ が増加して いる. また II 期の成功率が 80\%を超えるとスキル上達度合い が減少している.これらから, II 期の成功率が 60〜80\%付近 が最も訓練に効果的であると考えられる.

以上の結果から, 補正量がトレーニング効果に大きな影響 を及ぼし, base 条件が 3 条件の中で最も効果的であること が示された.つまり, 訓練者に適した調節量は訓練効果を高 めるために重要であると考えられ, 最大把持力の中央值を利
用して難易度を設定した base 条件は個人のスキルを反映し， 訓練に設定する難易度として適切であると示唆される.

\section{5. 長期訓練実験による訓練効果の検証}

\section{1.実験方法}

提案する手法に基づく訓練を 5 日間連続して行った際の訓 練効果を調查した。実験条件は第 4 節と同様であり, 毎日 Term I， II，IIIを繰り返し行った. 実験参加者は本研究に 関与しない 20 から 24 才の健常男子大学生, 院生であり, base 条件, $1 / 2$ 条件, 2 倍条件それぞれに対して 3 名ずつで あった. なお参加者には実験内容を十分説明し，同意を得た うえで実施した。

\section{2.実験結果}

Fig.12にII期におけるタスク成功率を示す. Mann-Whitney の U 検定の結果, 訓練条件間で有意な差 が認められた. Base 条件は, 2 倍条件および $1 / 2$ twice 条件 と比較し, 有意に II 期成功率が高かった $(\mathrm{p}<0.05$, $\mathrm{p}<0.001)$. また 2 倍条件における成功率は $1 / 2$ 条件よりも高 かった $(\mathrm{p}<0.001)$ 。つまり, 訓練中のタスク難易度は訓練条件 を変化させることによって適切に変化できた. なお, II 期成功 率は訓練日数による差が認められなかった。これは, 毎日 I 期にてスキルに応じたタスク難易度の設定しているためと考え られる。

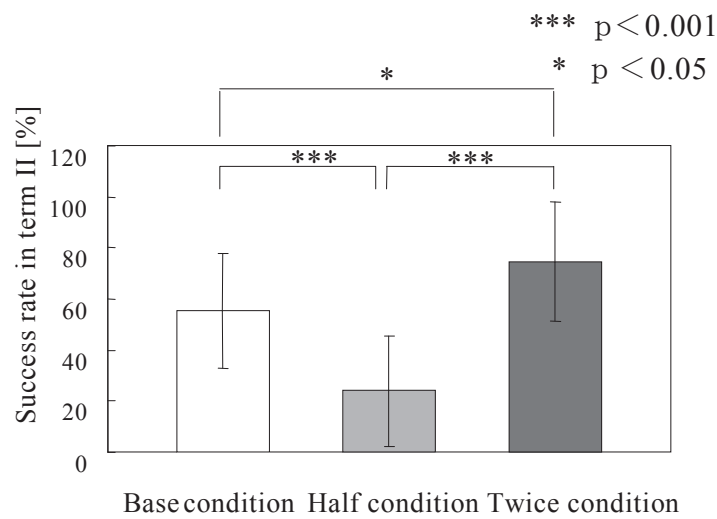

Fig.12. 長期訓練における II 期成功率

Fig.13 に, 式(6)で定義される成功率増加量を示す.これは 初日訓練前の状態を基準とした, 各日の訓練後の成功率増 加量である.

(成功率増加量)

$$
=(\text { 各日の III 期成功率 })-(\text { 初日の I 期成功率 })
$$

訓練が進むにつれ，III 期の成功率が上昇していることが見 て取れる. 1 日目のI期を基準とした 5 日目 III 期成功率は, 初日 III 期の成功率と比較して有意に増加した 


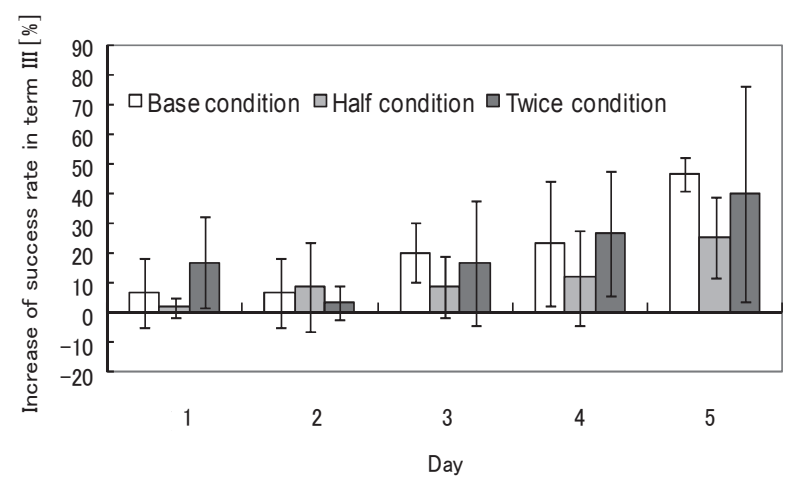

Fig.13. 長期訓練における成功率増加量

(Mann-Whitney U 検定, $\mathrm{p}<0.01)$. なお, 訓練条件間に ついて統計的有意差は認められなかったが，5日目において III期の成功率増加は, base 条件が最も高い傾向が見受けら れた.

\section{6. まとめ}

筋電義手操作における筋電位制御能力の効果的な訓練 を目的とし, 仮想環境を用いた訓練システムを開発した.

本論文では個人のスキルを調査する I 期, 訓練効果を検 証するIII期において, $F_{\max }$ と $F_{\min }$ を一定とした. より幅広い スキルレベルのユーザを対象とするには, この数值の設定に ついても個人毎に変更するなどの, 検討が必要と考えられ, 今後の課題である. またタスク難易度設定はタスク実行中の 筋疲労にも影響すると考えられるため, 疲労と訓練効果の関 係性について調査することも今後の課題である. 利用者の筋 電位制御能力を把握し, 能力に応じてタスク難易度を調整す る訓練手法を提案した. 実験結果から, タスク難易度調整に 基づく訓練手法により, 訓練タスクの成功率が適切に制御さ れ, 被験者の筋電位制御能力が効果的に向上することが示 された. なお夕スク難易度は, I 期における把持力の中央值 を用いるのが効果的であった. さらに提案手法の有効性は長 期訓練においても認められた.

本システムでは, 感覚フィードバックが視覚に制限されるた め, 画面上における物体の持ち上げ成功や, 物体破壊, 落 下による失敗など, タスクの正否が, 筋電位制御能力訓練に 利用できる情報となる.したがって, タスクの難易度が重要な 役割を果たすという結果を得た. 一方, 実際の筋電義手操作 においては把持による義手の重さ変化などの力覚, 触覚情 報も訓練に用いることができ, 視覚のみによる訓練とは異なる 作業戦略を獲得する可能性があるものの, そのような状況に おいても視覚フィードバックは不可欠であることから, 本実験 の結果は重要な知見であると考える.

今後の重要な課題として, 本手法で得られた訓練効果が, 筋電義手利用のスキル向上にどの程度寄与するかを調査す る必要がある. また, 物体持ち上げによる重量変化などの力 覚力を加味したシステムを構築し, 訓練効果を検証することも
今後の課題である. さらに, 筋電位を分離して出力するといっ た, 義手を扱うための他の基本的なスキルに対する, 提案訓 練手法の適用可能性を検証し, 提案システムの有用性拡大 を図る。

$$
\text { 参考文献 }
$$

[1] 大庭潤平, 陳隆明, 他, “片側前腕切断者における筋電 義手と能動義手の作業能力の比較”, 総合リ八, Vol.34,

No.7, pp.673-679, 2006

[2] 陳隆明, “筋電義手訓練マニュアル”, 全日本病院出版 会, 2006

[3] Otto Bock web page, www.ottobockus.com/

[4] Lovely, D.F., Stocker, D., Scott, R.N., "A Computer-aided Myoelectric Training System for Young Upper Limb Amputees", Journal of Microcomputer Applications, Vol.13, pp.245-259, 1990

[5] Dupont, A.C., Morin, E.L., A Myoelectric Contro Evaluation and Trainer System, IEEE Transactions on Rehabilitation Engineering, Vol.2, No.2, pp.100-107, 1994

[6]大里 真一, 大西 謙吾, “筋電位制御式義手の訓練に おける視鸴提示情報の効果”, 第 7 回生活支援工学系学 会連合大会予稿集，2009

[7]辻敏夫, 福田修, 大塚彰, 金子真, “義手制御を目的と した筋電操作トレーニングシステム”, 電子情報通信学会論 文誌, Vol.J83-D-II, No.10, pp.2030-2039, 2000 